\title{
TU/e Emphoven

\section{Si interstitial contribution of F+ implants in crystalline Si}

Citation for published version (APA):

López, P., Pelaz, L., Duffy, R., Meunier-Beillard, P., Roozeboom, F., Tak, van der, K., Breimer, P., Berkum, van, J. G. M., Verheijen, M. A., \& Kaiser, M. (2008). Si interstitial contribution of F+ implants in crystalline Si. Journal of Applied Physics, 103(9), [093538]. https://doi.org/10.1063/1.2917297

DOI:

10.1063/1.2917297

Document status and date:

Published: 01/01/2008

\section{Document Version:}

Publisher's PDF, also known as Version of Record (includes final page, issue and volume numbers)

\section{Please check the document version of this publication:}

- A submitted manuscript is the version of the article upon submission and before peer-review. There can be important differences between the submitted version and the official published version of record. People interested in the research are advised to contact the author for the final version of the publication, or visit the $\mathrm{DOI}$ to the publisher's website.

- The final author version and the galley proof are versions of the publication after peer review.

- The final published version features the final layout of the paper including the volume, issue and page numbers.

Link to publication

\section{General rights}

Copyright and moral rights for the publications made accessible in the public portal are retained by the authors and/or other copyright owners and it is a condition of accessing publications that users recognise and abide by the legal requirements associated with these rights.

- Users may download and print one copy of any publication from the public portal for the purpose of private study or research.

- You may not further distribute the material or use it for any profit-making activity or commercial gain

- You may freely distribute the URL identifying the publication in the public portal.

If the publication is distributed under the terms of Article 25fa of the Dutch Copyright Act, indicated by the "Taverne" license above, please follow below link for the End User Agreement:

www.tue.nl/taverne

Take down policy

If you believe that this document breaches copyright please contact us at:

openaccess@tue.nl

providing details and we will investigate your claim. 


\title{
Si interstitial contribution of $\mathrm{F}^{+}$implants in crystalline $\mathbf{S i}$
}

\author{
Pedro López, ${ }^{1, a)}$ Lourdes Pelaz, ${ }^{1}$ R. Duffy, ${ }^{2}$ P. Meunier-Beillard, ${ }^{2}$ F. Roozeboom, ${ }^{3}$ \\ K. van der Tak, ${ }^{4}$ P. Breimer, ${ }^{4}$ J. G. M. van Berkum, ${ }^{4}$ M. A. Verheijen, ${ }^{4}$ and M. Kaiser ${ }^{4}$ \\ ${ }^{1}$ Departamento de Electricidad y Electrónica, Universidad de Valladolid, Campus Miguel Delibes s/n, 47011 \\ Valladolid, Spain \\ ${ }^{2}$ NXP Semiconductors Research, Kapeldreef 75, 3001 Leuven, Belgium \\ ${ }^{3}$ NXP Semiconductors Research, High Tech Campus 4, 5656AE Eindhoven, The Netherlands \\ ${ }^{4}$ Philips Research Laboratories Eindhoven, High Tech Campus 11, 5656AE Eindhoven, The Netherlands
}

(Received 26 October 2007; accepted 5 March 2008; published online 13 May 2008)

\begin{abstract}
The $\mathrm{F}$ effect in crystalline $\mathrm{Si}$ is quantified by monitoring defects and $\mathrm{B}$ diffusion in samples implanted with $25 \mathrm{keV} \mathrm{F}^{+}$and/or $40 \mathrm{keV} \mathrm{Si}{ }^{+}$. We estimate that about $+0.4 \mathrm{Si}$ interstitials are generated per implanted $\mathrm{F}^{+}$ion, in agreement with the value resulting from the net separation of Frenkel pairs. For short annealings, B diffusion is lower when $\mathrm{F}^{+}$is coimplanted with $\mathrm{Si}^{+}$than when only $\mathrm{Si}^{+}$is implanted, while for longer annealings, $\mathrm{B}$ diffusion is higher. This is consistent with a lower but longer-lasting Si interstitial supersaturation set by the additional defects generated by the $\mathrm{F}^{+}$implant. (C) 2008 American Institute of Physics. [DOI: 10.1063/1.2917297]
\end{abstract}

\section{INTRODUCTION}

In the fabrication of ultrashallow $p$-type junctions in complementary metal oxide semiconductor technology, $\mathrm{B}^{+}$ has been traditionally coimplanted with $\mathrm{F}^{+}$because of the technological advantage of using $\mathrm{BF}_{2}^{+}$. More recently, specially designed cocktail implants combine separate $\mathrm{B}^{+}$and $\mathrm{F}^{+}$implants in preamorphized $\mathrm{Si}$ to optimize the junction formation. ${ }^{1}$ It has been clearly demonstrated that the presence of $\mathrm{F}$ inside the recrystallized layer strongly reduces $\mathrm{B}$ diffusion. ${ }^{2,3}$ This beneficial effect has been related to the formation of F-vacancy complexes $\left(\mathrm{F}_{n} V_{m}\right)$ during solid phase epitaxial regrowth of the preamorphized layer, acting as annihilation centers for Si interstitials $(I$ 's) released from end of range (EOR) defects, reducing $\mathrm{Si} I$ 's supersaturation, and thus, B diffusion.

The mechanisms governing $\mathrm{F}$ behavior in crystalline $\mathrm{Si}$ $(c-\mathrm{Si})$ and its effect on B diffusion have not been fully elucidated yet. There is not even an agreement about a possible beneficial effect of $\mathrm{F}^{+}$implantation in $c$-Si. Some experiments indicate that medium energy $\mathrm{F}^{+}$implants cause $\mathrm{B}$ transient enhanced diffusion (TED) although less than that caused by equivalent $\mathrm{Si}^{+}$or $\mathrm{Ne}^{+}$implants. ${ }^{4}$ Other studies with high energy $\mathrm{F}^{+}$implants have reported a $\mathrm{B}$ diffusion even lower than equilibrium in the vacancy-rich region of the damage profile, ${ }^{5}$ but this also occurs for other high energy ion implants. ${ }^{6}$ Park et al. showed that annealed B profiles of nonamorphizing $\mathrm{BF}_{2}^{+}$implants are shallower than the equivalent B implants but they have a higher electrical resistivity. ${ }^{7}$ The clarification of the role of $\mathrm{F}$ in $c$-Si is important because sometimes, amorphization should be avoided due to the excessive leakage caused by residual EOR defects or because the imperfect recrystallization degrades device performance, as it occurs in thin fin field effect transistor structures. ${ }^{8}$ The aim of this work is to elucidate the role of the $\mathrm{F}^{+}$coimplantation on $\mathrm{B}$ diffusion in $c$-Si.

\footnotetext{
${ }^{a)}$ Author to whom correspondence should be addressed. Electronic mail: pedrol@ele.uva.es.
}

\section{EXPERIMENTAL PROCEDURE}

In our experiments, two B doped layers were grown by chemical vapor deposition at depths of 120 and $440 \mathrm{~nm}$ to act as diffusion markers. B peak concentration was low, approximately $2.5 \times 10^{18} \mathrm{~cm}^{-3}$, to minimize the formation of boron interstitial clusters (BICs). Two different nonamorphizing $\mathrm{F}$ fluences $\left(1 \times 10^{14}\right.$ and $\left.5 \times 10^{14} \mathrm{~cm}^{-2}\right)$ were chosen to analyze the effect of the amount of damage and $\mathrm{F}$ fluence on $\mathrm{B}$ diffusion. $\mathrm{F}^{+}$was implanted at $25 \mathrm{keV}$ whose mean projected range $\left(R_{p}\right)(\sim 56 \mathrm{~nm})$ is located close to the position of the shallow B spike. A $40 \mathrm{keV} 5 \times 10^{13} \mathrm{~cm}^{-2} \mathrm{Si}^{+}$ implant, whose $R_{p}$ is similar to that of the $\mathrm{F}^{+}$implants, was also performed alone or combined with one of the two $\mathrm{F}^{+}$ implants to study the effect of $\mathrm{F}$ with additional damage. A sample with no implants was used as a reference for equilibrium $\mathrm{B}$ diffusion. All samples were annealed at $850^{\circ} \mathrm{C}$ for 18,180 , or $1800 \mathrm{~s}$. Secondary ion mass spectrometry (SIMS) was used to analyze $\mathrm{B}$ and $\mathrm{F}$ profiles and transmission electron microscopy (TEM) to detect the presence of extended defects.

\section{RESULTS AND DISCUSSION}

SIMS B profiles for the samples implanted with $\mathrm{F}^{+}, \mathrm{Si}^{+}$, and $\mathrm{F}^{+}$plus $\mathrm{Si}^{+}$after annealing at $850{ }^{\circ} \mathrm{C}$ for $18 \mathrm{~s}$ are plotted in Fig. 1. We observe that $\mathrm{F}^{+}$implants alone lead to enhanced B diffusion compared to equilibrium, which indicates that a $\mathrm{F}^{+}$implant generates a Si I's supersaturation, as previously reported. ${ }^{4}$ However, for this short annealing, B diffusion is reduced when a $\mathrm{F}^{+}$implant is added to the $\mathrm{Si}^{+}$implant, compared to the samples that are only implanted with $\mathrm{Si}^{+}$. This reduction is observed in both $\mathrm{B}$ spikes and for the two $\mathrm{F}^{+}$ fluences but it is clearer for the lower $\mathrm{F}^{+}$fluence. When $10^{14} \mathrm{~cm}^{-2} \mathrm{~F}^{+}$is coimplanted with $\mathrm{Si}^{+}, \mathrm{B}$ diffusivity in the deep B spike is about 0.6 times that obtained in the sample implanted only with $\mathrm{Si}^{+}$. The situation changes as the annealing proceeds, as we can see in the SIMS profiles plotted in Fig. 2 corresponding to $180 \mathrm{~s}$ annealings. For the lower $\mathrm{F}^{+}$ 


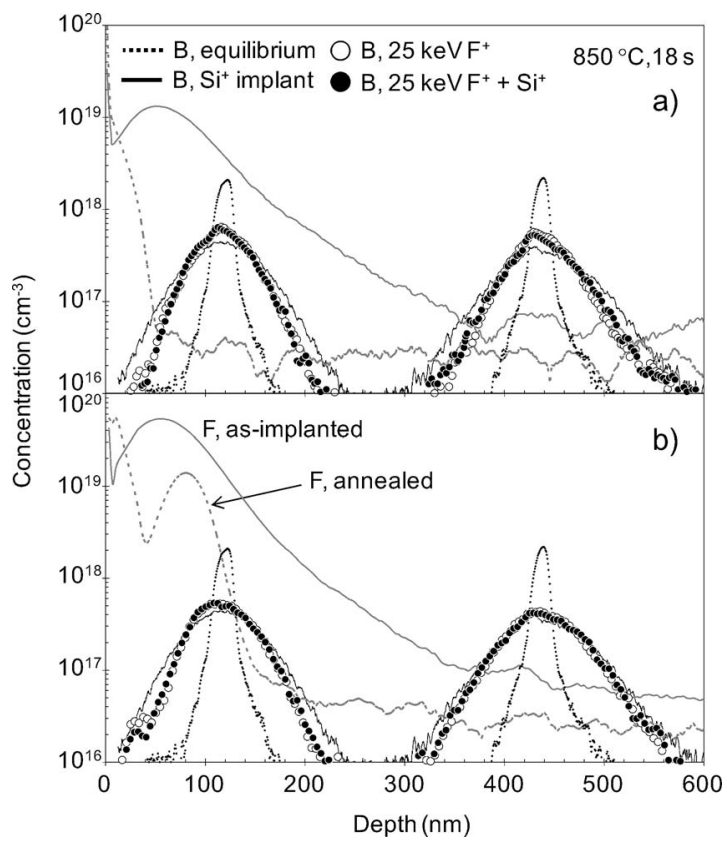

FIG. 1. B SIMS profiles after annealing at $850{ }^{\circ} \mathrm{C}$ for $18 \mathrm{~s}$ in the samples implanted with $5 \times 10^{13} \mathrm{~cm}^{-2} 40 \mathrm{keV} \mathrm{Si}{ }^{+}$(solid black line), $25 \mathrm{keV} \mathrm{F}^{+}$ (open symbols), or coimplanted with $\mathrm{Si}^{+}$and $\mathrm{F}^{+}$in the same conditions (solid symbols). Two $\mathrm{F}$ fluences were implanted: (a) $10^{14} \mathrm{~cm}^{-2} \mathrm{~F}^{+}$and (b) $5 \times 10^{14} \mathrm{~cm}^{-2} \mathrm{~F}^{+}$. The diffused $\mathrm{B}$ profiles in equilibrium conditions (dotted black line) are plotted for comparison. The as-implanted and annealed $\mathrm{F}$ profiles for both implants are also shown (solid and dotted gray lines).

fluence, the advantage of $\mathrm{F}^{+}$coimplantation is no longer observed and a higher $\mathrm{B}$ diffusion appears when $\mathrm{F}^{+}$and $\mathrm{Si}^{+}$are coimplanted compared to the sample only implanted with $\mathrm{Si}^{+}$ (approximately 1.7 times higher). At this time, samples im-

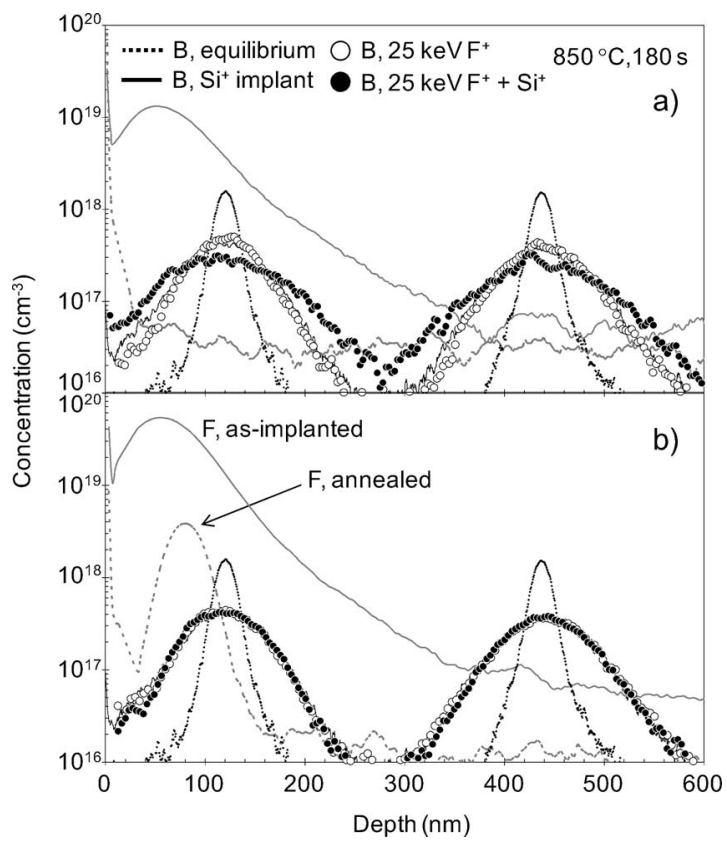

FIG. 2. B SIMS profiles after annealing at $850{ }^{\circ} \mathrm{C}$ for $180 \mathrm{~s}$ in the samples implanted with $5 \times 10^{13} \mathrm{~cm}^{-2} 40 \mathrm{keV} \mathrm{Si}^{+}$(solid black line), $25 \mathrm{keV} \mathrm{F}^{+}$ (open symbols), or coimplanted with $\mathrm{Si}^{+}$and $\mathrm{F}^{+}$in the same conditions (solid symbols). Two F fluences were implanted: (a) $10^{14} \mathrm{~cm}^{-2} \mathrm{~F}^{+}$and (b) $5 \times 10^{14} \mathrm{~cm}^{-2} \mathrm{~F}^{+}$. The diffused B profiles in equilibrium conditions (dotted black line) are included. The as-implanted and annealed $\mathrm{F}$ profiles are also plotted (solid and dotted gray lines). planted with $5 \times 10^{14} \mathrm{~cm}^{-2} \mathrm{~F}^{+}$(alone or coimplanted) present similar B diffusion to the one implanted only with $\mathrm{Si}^{+}$. The B SIMS profiles for $1800 \mathrm{~s}$ (not shown) are similar to those at $180 \mathrm{~s}$.

The as-implanted and annealed F SIMS profiles are also plotted in Figs. 1 and 2 for 18 and 180 s annealings, respectively. Only the shallow B spike is initially covered by $\mathrm{F}$ and a significant fraction of $\mathrm{F}$ is lost upon annealing. For the higher $\mathrm{F}^{+}$implant fluence, there is a $\mathrm{F}$ peak located around $R_{p}$ that remains long. For the $10^{14} \mathrm{~cm}^{-2} \mathrm{~F}^{+}$implant, only $24 \%$ of $\mathrm{F}$ fluence is retained after $18 \mathrm{~s}$ annealing and it is located very close to the surface. It has almost completely outgassed after $180 \mathrm{~s}$. Since F rapidly outdiffuses, and theoretical calculations indicate that the $\mathrm{F}-\mathrm{B}$ interaction is weak, ${ }^{3}$ it is unlikely that the immobilization of $\mathrm{B}$ atoms by $\mathrm{F}$ is responsible for the reduction of $\mathrm{B}$ diffusion. It is worthy to note that less B diffusion is observed in the shallow B spike (initially covered by F) than in the deepest one but this also happens for the $\mathrm{Si}^{+}$implant. This behavior could be explained by the temporal immobilization of $\mathrm{B}$ due to the formation of BICs in the damaged region of the $\mathrm{F}^{+}$or $\mathrm{Si}^{+}$ implants, ${ }^{9}$ which reduces the amount of B available for diffusion. The additional damage cascades generated by the $\mathrm{F}^{+}$ coimplantation with $\mathrm{Si}^{+}$would favor BIC formation in the shallow B spike, and thus, a reduction in B diffusion. In fact, Park et al. reported a significantly lower effective solubility of $\mathrm{B}$ in $\mathrm{BF}_{+}{ }^{2}$ implants compared to equivalent $\mathrm{B}^{+}$implants. ${ }^{7}$ In our experiment, since $\mathrm{B}$ concentration is low, only a small $\mathrm{B}$ fraction is expected to be in BICs and they would easily dissolve at $850{ }^{\circ} \mathrm{C}$. In any case, the deep B spike is not covered by F or by the implant damage (no BICs are formed) and it also undergoes a reduced B diffusion for short annealing times in samples coimplanted with $\mathrm{F}^{+}$and $\mathrm{Si}^{+}$compared to those only implanted with $\mathrm{Si}^{+}$. Therefore, $\mathrm{F}$ has a nonlocal effect on B diffusion, which may be attributed to a modification in the Si I's supersaturation set by the defect evolution.

In the sample implanted only with $\mathrm{Si}^{+}$, no defects are observed in TEM images (not shown) after annealing at $850{ }^{\circ} \mathrm{C}$ for $18 \mathrm{~s}$. It is known that a $5 \times 10^{13} \mathrm{~cm}^{-2} 40 \mathrm{keV} \mathrm{Si}^{+}$ implant produces small Si I's clusters and $\{113\}$ defects that set a high Si I's supersaturation but quickly dissolve. ${ }^{10}$ TEM images of the sample coimplanted with $\mathrm{Si}^{+}$and $10^{14} \mathrm{~cm}^{-2}$ $\mathrm{F}^{+}$, included in Fig. 3, show a high defect density after $18 \mathrm{~s}$ annealing. After $180 \mathrm{~s}$ annealing, most defects have dissolved and only a few $\{113\}$ defects are visible [Fig. 3(b)]. TEM analysis of the sample implanted with $5 \times 10^{14} \mathrm{~cm}^{-2}$ $\mathrm{F}^{+}$reveals a large number of $\{113\}$ defects and dislocation loops for $18 \mathrm{~s}$ annealing [Fig. 3(c)]. After $1800 \mathrm{~s}$ annealing, many dislocation loops still remain [Fig. 3(d)].

An important difference between $\mathrm{F}^{+}$implantation in amorphous $\mathrm{Si}(a-\mathrm{Si})$ and $c-\mathrm{Si}$ is that in $a-\mathrm{Si}$, some vacancies $\left(V\right.$ 's) can be retained into the lattice as $\mathrm{F}_{n} V_{m}$ complexes while excess $\mathrm{Si}$ atoms are swept to the surface during regrowth, resulting in a net excess vacancy contribution associated to the presence of $\mathrm{F}$. In $c$-Si, $I$ 's and $V$ 's are created in pairs, plus one additional excess Si interstitial per implanted ion if this becomes substitutional (not likely in the case of F). ${ }^{11}$ If $\mathrm{F}_{n} V_{m}$ complexes are formed, the amount of excess 


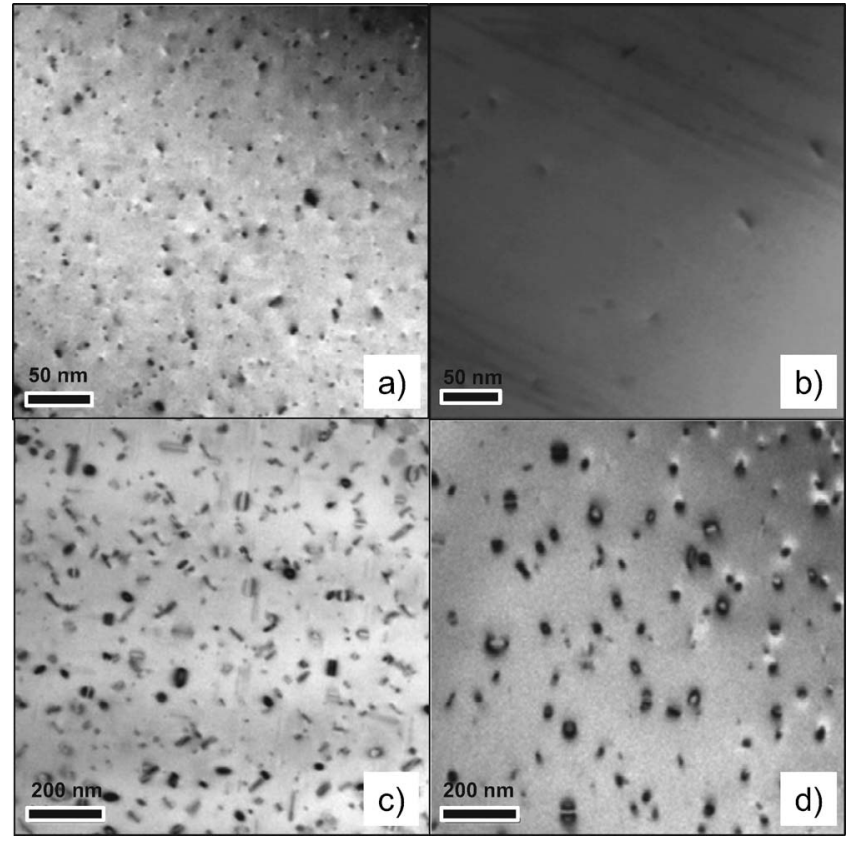

FIG. 3. [(a) and (b)] Plan-view TEM images for $10^{14} \mathrm{~cm}^{-2} 25 \mathrm{keV} \mathrm{F}^{+}$plus $5 \times 10^{13} \mathrm{~cm}^{-2} 40 \mathrm{keV} \mathrm{Si}{ }^{+}$after annealing at $850{ }^{\circ} \mathrm{C}$ for 18 and $180 \mathrm{~s}$, respectively. [(c) and (d)] Plan view TEM images for $5 \times 10^{14} \mathrm{~cm}^{-2} 25 \mathrm{keV}$ $\mathrm{F}$ after annealing at $850{ }^{\circ} \mathrm{C}$ for 18 and $1800 \mathrm{~s}$.

Si $I$ 's per $\mathrm{F}$ atom would correspond to the number of $V$ 's retained per $\mathrm{F}$ atom $(\mathrm{m} / \mathrm{n})$. Frenkel pairs can be locally separated due to the momentum transfer of the energetic incoming ions, and a vacancy-rich region is created near the surface and a $\mathrm{Si}$ self-interstitial-rich region deeper. ${ }^{12}$ In the $\mathrm{Si}$ interstitial-rich region, $\mathrm{F}_{n} V_{m}$ complexes are not likely to survive because the excess Si $I$ 's will easily recombine them ${ }^{3}$ and $\mathrm{F}$ would outdiffuse or segregate to extended defects. A chemical role of $\mathrm{F}$ could be derived from the trapping of Si $I$ 's in $\mathrm{F}_{n} I_{m}$ complexes, ${ }^{13}$ although theoretical calculations indicate that $\mathrm{F}$ and Si I's are not strongly bound. ${ }^{3}$ Some authors suggested the modification of Si self-interstitial defect stability, ${ }^{14}$ while others indicated that $\mathrm{F}$ did not have an effect on defect evolution. ${ }^{15}$ In any case, a change in defect stability or the temporary trapping of Si I's would alter B diffusion during the transient period (while defects or complexes exist), but once defects had been completely annealed out and all Si I's were released, the overall B diffusion should correspond to the excess Si I's generated independently of the stability of defects or complexes where they may have been temporarily stored. ${ }^{16}$ An additional contribution of $\mathrm{F}$ could be attributed to its transport capability of point defects. If the dominant diffusing species were interstitial $\mathrm{F}\left(\mathrm{F}_{i}\right),{ }^{3} \mathrm{~F}$ would only transport itself and the implanted ion would outdiffuse without altering the damage balance associated with the Frenkel pair separation. Nevertheless, if the $\mathrm{F}_{i}$-interstitial pair $\left(\mathrm{F}_{i}-I\right)$ significantly diffused as it has been recently suggested, ${ }^{17}$ the presence of $F$ would favor the removal of Si $I$ 's, leaving excess $V$ 's behind. The contrary would hold if the main diffusing species were the $\mathrm{F}_{i^{-}} V$ pair.

In order to quantify the Si interstitial damage produced by the $\mathrm{F}^{+}$implant and its net contribution to $\mathrm{B}$ diffusion, we have determined from TEM images (according to the quan- tification method described elsewhere) ${ }^{18-20}$ that approximately $2 \times 10^{14} \mathrm{Si} I$ ' $\mathrm{s} / \mathrm{cm}^{2}$ are stored in the $\{113\}$ defects and dislocation loops for the $25 \mathrm{keV} 5 \times 10^{14} \mathrm{~cm}^{-2} \mathrm{~F}^{+}$implant after $18 \mathrm{~s}$ annealing (typical error is $20 \%$ ). The defects observed in TEM images at short times (when defects have ripened enough to be visible but before a significant part of them has dissolved) give an estimate of the initial amount of defects. This value is a lower limit since some defects may not be visible or may have already dissolved. Thus, we experimentally estimate that around $0.4, \mathrm{Si} I$ 's per implanted $\mathrm{F}^{+}$ ion are stored in defects. An estimate of the effective number of Si I's can also be derived from diffusion experiments when TED is complete. For the longest annealing time analyzed (defects are completely dissolved), the averaged value of the B diffusivity multiplied by time (which is proportional to the time integrated free $\mathrm{Si}$ interstitial concentration) in the deep B spike for the $25 \mathrm{keV} 10^{14} \mathrm{~cm}^{-2} \mathrm{~F}^{+}$implant alone is about 0.7 times that of the $40 \mathrm{keV} 5 \times 10^{13} \mathrm{~cm}^{-2} \mathrm{Si}^{+}$implant, while for the $\mathrm{F}^{+}$and $\mathrm{Si}^{+}$coimplantation, this value is equal to 1.7 times that of the $\mathrm{Si}$. Therefore, the contribution of this $\mathrm{F}^{+}$implant (whose $R_{p}$ is similar to that of the $\mathrm{Si}^{+}$ implant) is about 0.7 times that of the $\mathrm{Si}^{+}$implant, although the $\mathrm{F}^{+}$implant fluence is double the Si fluence. Considering that the effective $+n$ factor for the $\mathrm{Si}^{+}$implant is approximately $+1.3,{ }^{12}$ this indicates that the number of effective $\mathrm{Si} I$ 's per implanted $\mathrm{F}^{+}$ion in $c$-Si is about +0.5 , which is significantly lower than unity. Theoretical calculations reveal that $\mathrm{F}$ prefers to remain interstitial rather than to occupy a substitutional position, ${ }^{11}$ which explains this low value, and why $\mathrm{F}^{+}$implants produce less TED than similar $\mathrm{Si}^{+}$or $\mathrm{Ne}^{+}$ implants. ${ }^{4}$

Kinetic Monte Carlo simulations of the $25 \mathrm{keV} \mathrm{F}^{+}$implant reveal that once the Frenkel pairs have locally recombined, there are approximately $0.4 \mathrm{Si} I$ 's per implanted $\mathrm{F}^{+}$ ion in the interstitial-rich region, in good agreement with the values estimated experimentally. Therefore, the net separation between Si I's and the corresponding $V$ 's resulting from the $\mathrm{F}^{+}$implant in $c$-Si accounts for the presence of $\mathrm{Si}$ interstitial-type defects and the measured enhanced B diffusion. This also indicates that $\mathrm{F}_{i}$ has no significant transport capability of additional point defects. Although we cannot rule out a chemical role of $\mathrm{F}$ stabilizing extended defects, the additional damage created by the $\mathrm{F}^{+}$coimplant with $\mathrm{Si}^{+}$also contributes to the formation of a larger defect density, favoring their growth by the capture of emitted Si I's and setting a lower Si I's supersaturation responsible for the reduced $\mathrm{B}$ TED for short annealing times. The coimplantation of $\mathrm{Si}^{+}$ and the lower $\mathrm{F}^{+}$fluence causes a higher B TED for longer annealings because more $\mathrm{Si} I$ 's (those generated by both $\mathrm{Si}^{+}$ and $\mathrm{F}^{+}$implants) have contributed to it. The samples implanted with a higher $\mathrm{F}^{+}$fluence $\left(5 \times 10^{14} \mathrm{~cm}^{-2}\right)$ do not show more $\mathrm{B}$ diffusion than that implanted only with $\mathrm{Si}^{+}$, even for the longest analyzed annealing (1800 s), in spite of the much larger effective $\mathrm{Si}$ interstitial fluence contribution for the $\mathrm{F}^{+}$implant $\left[\sim 2 \times 10^{14} \mathrm{~cm}^{-2}\right.$ for $\mathrm{F}^{+}(0.4 \times$ implant fluence) versus $\sim 6.5 \times 10^{13} \mathrm{~cm}^{-2}$ for $\mathrm{Si}^{+}(1.3 \times$ implant fluence)] because many $I$ 's still remain stored in stable dislocation loops ${ }^{21}$ and have not effectively contributed to enhance B diffusion. 


\section{CONCLUSIONS}

In summary, from TEM images and B diffusion experiments, we have estimated that approximately $+0.4 \mathrm{Si} I$ 's are generated per implanted $25 \mathrm{keV} \mathrm{F}^{+}$ion, in good agreement with the value resulting from the net separation of Frenkel pairs. Although other effects cannot be completely ruled out, the overall resulting effect of $\mathrm{F}$ on $\mathrm{B}$ diffusion can be explained on the basis of the defect evolution. The additional Si I's generated by $\mathrm{F}^{+}$coimplants contribute to the formation of a larger amount of more stable extended defects, which set a lower but longer-lasting $\mathrm{Si}$ interstitial supersaturation. As a result, at short annealing times a reduction of B diffusion is observed, but if the annealing is complete (which is desirable to reduce junction leakage), B diffusion is enhanced by the additional $\mathrm{F}^{+}$implant. Our results clearly indicate that $\mathrm{F}^{+}$ coimplantation with $\mathrm{Si}^{+}$(or normally $\mathrm{B}^{+}$implant) in $c$-Si causes additional $\mathrm{Si}$ interstitial defects and it has an overall negative effect on junction formation.

\section{ACKNOWLEDGMENTS}

This work has been funded by the Spanish DGI under Project No. TEC2005-05101 and the JCyL Consejería de Educación y Cultura under Project No. VA070A05.

${ }^{1}$ E. J. H. Collart, S. B. Felch, H. Graoui, D. Kirkwood, S. Tallavarjula, J. A. Van den Berg, J. Hamilton, N. E. B. Cowern, and K. J. Kirkby, Mater. Sci. Eng., B 114, 118 (2004).

${ }^{2}$ G. Impellizzeri, S. Mirabella, F. Priolo, E. Napolitani, and A. Carnera, J. Appl. Phys. 99, 103510 (2006).

${ }^{3}$ G. M. Lopez, V. Fiorentini, G. Impellizzeri, S. Mirabella, and E. Napolitani, Phys. Rev. B 72, 045219 (2005).

${ }^{4}$ H.-H. Vuong, H.-J. Gossman, C. S. Rafferty, H. S. Luftman, F. C. Unterwald, D. C. Jacobson, R. E. Ahrens, T. Boone, and P. M. Zeitzoff, J. Appl.
Phys. 77, 3056 (1995).

${ }^{5}$ H. A. W. El Mubarek, J. M. Bonar, G. D. Dilliway, P. Ashburn, M. Karunaratne, A. F. Willoughby, Y. Wang, P. L. F. Hemment, R. Price, J. Zhang, and P. Ward, J. Appl. Phys. 96, 4114 (2004).

${ }^{6}$ V. C. Venezia, T. E. Haynes, A. Agarwal, L. Pelaz, H.-J. Gossmann, D. C. Jacobson, and D. J. Eaglesham, Appl. Phys. Lett. 74, 1299 (1999).

${ }^{7}$ J. Park, Y.-J. Huh, and H. Hwang, Appl. Phys. Lett. 74, 1248 (1999).

${ }^{8}$ R. Duffy, M. J. H. Van Dal, B. J. Pawlak, M. Kaiser, B. Degroote, E. Kunnen, and E. Altamirano, Appl. Phys. Lett. 90, 241912 (2007).

${ }^{9}$ L. Pelaz, M. Jaraiz, G. H. Gilmer, H.-J. Gossman, C. S. Rafferty, D. J. Eaglesham, and J. M. Poate, Appl. Phys. Lett. 70, 2285 (1997).

${ }^{10}$ D. J. Eaglesham, P. A. Stolk, H.-J. Gossman, and J. M. Poate, Appl. Phys. Lett. 65, 2305 (1994).

${ }^{11}$ M. Diebel and S. T. Dunham, Si Front-End Junction Formation Technologies, MRS Symposia Proceedings No. 717 (Materials Research Society, Pittsburgh, 2002), p. C4.5.1.

${ }^{12}$ L. Pelaz, G. H. Gilmer, M. Jaraiz, S. B. Herner, H.-J. Gossmann, D. J. Eaglesham, G. Hobler, C. S. Rafferty, and J. Barbolla, Appl. Phys. Lett. 73, 1421 (1998).

${ }^{13}$ R. R. Robison and M. E. Law, Tech. Dig. - Int. Electron Device Meet. 2002, 883.

${ }^{14}$ F. Cristiano, Y. Lamrani, F. Severac, M. Gavelle, S. Boninelli, N. Cherkashin, O. Marcelot, A. Claverie, W. Lerch, S. Paul, and N. E. B. Cowern, Nucl. Instrum. Methods Phys. Res. B 253, 68 (2006).

${ }^{15}$ D. F. Downey, J. W. Chow, E. Ishida, and K. S. Jones, Appl. Phys. Lett. 73, 1263 (1998)

${ }^{16}$ C. S. Rafferty, G. H. Gilmer, M. Jaraiz, D. J. Eaglesham, and H.-J. Gossman, Appl. Phys. Lett. 68, 2395 (1996).

${ }^{17}$ S. A. Harrison, T. F. Edgar, and G. S. Hwang, Phys. Rev. B 74, 121201(R) (2006).

${ }^{18}$ D. J. Eaglesham, P. A. Stolk, H.-J. Gossman, and J. M. Poate, Appl. Phys. Lett. 65, 2305 (1994).

${ }^{19}$ N. Cherkashin, P. Calvo, F. Cristiano, B. de Mauduit, and A. Claverie, Silicon Front-End Junction Formation-Physics and Technology, MRS Symposia Proceedings No. 810 (Materials Research Society, Pittsburgh, 2004), p. 103.

${ }^{20}$ J. K. Listebarger, K. S. Jones, and J. A. Slinkman, J. Appl. Phys. 73, 4815 (1993).

${ }^{21}$ F. Cristiano, J. Grisolia, B. Colombeau, M. Omri, B. de Mauduit, A. Claverie, L. F. Giles, and N. E. B. Cowern, J. Appl. Phys. 87, 8420 (2000). 